\title{
EFFECT OF COCONUT MILK INCLUSION IN ROOT MEAL-BASED DIETS ON PERFORMANCE AND FEED INTAKE OF NATIVE CHICKENS
}

\author{
Albino TAER ${ }^{\circledR 凶}$, Erma TAER², Edwin ESCOBAL³ ${ }^{3}$ Ludy ALSONG44 , and Romana MAGLINTE2 \\ 1 Lecturer, Department of Poultry, Surigao State College of Technology-Mainit Campus, Mainit 8407, Surigao, Philippines \\ 2Faculty of Agriculture, Department of Agronomy, Surigao State College of Technology-Mainit Campus, Mainit 8407, Surigao, Philippines \\ ${ }^{3}$ Faculty of Agroforestry, Department of Agroforestry, Surigao State College of Technology-Mainit Campus, Mainit 8407, Surigao, Philippines \\ ${ }^{4}$ Lecturer, Department of Agronomy, Surigao State College of Technology-Mainit Campus, Mainit 8407, Surigao, Philippines \\ Email: albinotaer74@gmail.com; (D) ORCiD: 0000-0002-2958-4682 \\ supporting Information
}

ABSTRACT: In pursuit of feed cost reduction for chickens, a reduced feed intake strategy was proposed, but how this strategy works without compromising the chicken performance rarely explored. This study proposes the satiating effects of fresh coconut milk (FCM) as dietary fat for giant swamp taro meal-based (GST) diets on the performance and feed intake reduction of native chickens. One hundred eighty Bisaya native chickens have been grouped into FCM-free and FCM supplemented groups further divided into $0 \%, 25 \%$, and $50 \%$ GST sub-groups of ten chickens in each sub-group. The experiment was laid out in a $2 \times 3$ factorial in a completely randomized design. The feeding trial started on week 5 post-hatch and terminated on week 12 post-hatch. The average daily feed intake (ADFI) and weight gain (WG) of chicken at weekly intervals were highly significant among FCM as well as GST treatments during weeks 5-7, also the final ADFI and WG. However, no remarkable differences of ADFI and WG in weeks 8-12 feeding. The bodyweight of chickens was highly significant among the FCM group and levels of GST were consistently observed throughout the study period. Neither the FCM nor GST groups differ the values for FCR. However, a bit higher FCR for FCM supplemented and 0\% GST treatments. Slaughter weight, meat cuts (breast and thigh) and organ weight (liver, gizzard, and heart) was uninfluenced by either FCM or levels of GST. FCM supplemented diet had higher apparent digestibility of crude ash than FCM-free. 25\% GST meal inclusion had higher apparent digestibility of crude fiber compared to $0 \%$ and $50 \%$ GST. No remarkable FCM $\times$ GST interactions in all parameters tested throughout the trial. In conclusion, supplementation of fresh coconut milk to giant swamp taro meal as replacement to maize did not reduce feed intake of chickens but rather increased body weight, weight gain with marginal improvement in FCR. The $50 \%$ giant swamp taro replacement to maize compromises overall performance of native chickens. However, supplementing fresh coconut milk to giant swamp taro meal can replace maize up to $25 \%$ that gives a better body weight, weight gain, and feed conversion ratio.

Keywords: Bisaya native chicken, Coconut, Dietary fats, Feed efficiency, Root crops.

\section{INTRODUCTION}

Feed cost accounts for $70-80 \%$ of the total production expenses for poultry farms (Mallick et al., 2020), but what many feed millers and researchers may not realize is how to develop a diet that has higher satiation effects that will reduce feed intake to help alleviate the current problem. Satiation means the process which brings eating to a halt, while satiety is the state of inhibition over further eating (Blundell, 1984). Satiation occurs during an eating episode and brings it to an end. Satiety starts after the end of eating and prevents further eating before the return of hunger. Enhancing satiation and satiety derived from foodstuffs was perceived as a means to facilitate feed intake and weight control (Bellisle et al., 2012).

Hunger and satiety are affected by the nutritional composition and structure of foods: therefore, some foods have a greater capacity to maintain suppression over appetite than others (Pickering and Halford, 2016). When expressed relative to energy content rather than the weight of food, protein exerts the most substantial effect on satiety, followed by carbohydrate, while fat exerts the weakest effect (Blundell et al., 1993; Hopkins et al., 2016). In humans, the protein content of a food or meal is also a factor in the short-term reduction of food intake (Anderson and Moore, 2004). Because protein as a feed ingredient for chicken is scarcer than carbohydrates, providing a high-protein diet beyond tissue building is inefficient. The study between low-fat high carbohydrate (LFHC) and high fat low carbohydrate (HFLC) for overweight and obese individuals suggests that LFHC foods promote reduced energy intake (Hopkins et al., 2016), demonstrating LFHC diets are effective for long-term weight loss. However, high carbohydrate as energy feed ingredients is the largest in terms of quantity $(40-70 \%)$ for a poultry diet and are becoming scarce and invariably the most expensive (Skinner et al., 1992; Van der Klis, 2010) due to stiff competition as it used by industries for biofuel and as food for humans (Ahiwe et al., 2018). Fats are the most energy-dense of the macronutrients at $9.5 \mathrm{kcal}$ per gram, and high-fat diets (in comparison with low-fat and high-carbohydrate diets) have a disproportionately weak action on satiety (Pickering and Halford, 2016). In terms of affordability and availability, fats can be considered the cheapest and the most abundant than other macronutrient proteins and carbohydrates (Ravindran et al., 2016). 
The use of non-conventional proteins and energy sources to substitute soybean and maize in monogastric animals is currently a worldwide effort. Some non-conventional feed ingredients such as the "Palau" root crop (Cyrtosperma merkusii) are commonly used to replace maize due to their availability, being less utilized by humans, and being of economic importance (Taer and Taer, 2020). However, taro diet inclusion is very poor due to anti-nutritional factors that decreased feed intake and growth performance. Additionally, the problem with this root crop was that taro has lower nutrient densities affecting performance and efficiency than maize and other non-conventional feedstuffs (Temesgen and Retta, 2015; Temesgen et al., 2017).

The addition of fresh coconut milk as dietary fat for a root meal-based diet will improve the energy density of root starches and is expected to enhance the productivity of poultry. The effect of fats on satiety has been investigated in four areas associated with fat structure: chain length, degree of saturation, degree of esterification, and functionality of specific fat molecules (Samra, 2010). In fat chain length, coconut milk has a high percentage of a medium-chain fatty acid beneficial to increase weight without increasing cholesterol levels (St-Onge and Jones, 2002; Wallace, 2019). Coconut consists of fatty acids that work as the source of energy and antimicrobial effects. The study of coconut milk as one alternative to improve the immune system when birds are in stress or uncomfortable housing conditions (Shakeri et al., 2016). Dietary fat addition slows down digestion passage rate through the gastrointestinal tract, allowing better nutrient digestion, absorption, and utilization (Mateos et al. 1982; Latshaw, 2008), probably through increased contact with digestive enzymes. Several mechanisms, including regulation of Ghrelin (appetite hormones) and inhibition of gastric emptying and intestinal transit, are perceived fats that affected satiety (Samra, 2010). A study in humans also found that food intake at lunch was lower after a high medium chain triglyceride (MCT) breakfast when compared to high oleic or high saturated fat breakfast in men (Van Citters and Lin, 1999). Another research found lower intake at dinner after a high medium chain triglycerides consumption at lunch (Van Wymelbeke et al., 1998). The reason for using coconut milk instead of coconut oil was related to high levels of saturated fat in coconut oil which can increase the level of harmful LDL-cholesterol in the blood (Gómez et al., 2000).

While these findings indicate that the higher inclusion of medium-chain fatty acids in coconut milk potentially lowers feed intake and increased weight without increasing cholesterol level in humans, the effect of the same, on feed intake and weight gain for chickens has yet to be determined. Hence, this study aimed to investigate the effects levels of giant swamp taro meal as a replacement for maize added with or without coconut milk on the growth performance, feed intake reduction, and efficiency of native chicken. This preliminary study focused on the performance and feed intake reduction effect and fat accumulation of fresh coconut milk as dietary fat concerning satiety.

\section{MATERIALS AND METHODS}

\section{Study location and ethical regulations}

The study was supervised and approved by the research committee of the department of agriculture, in compliance with the rules and regulations on the scientific procedures using animals under the Philippines Republic No. 8485, otherwise known as the "Animal Welfare Act of 1998". The experimental setup was at the poultry facility in the Department of Animal Science of Surigao State College of Technology-Mainit Campus, in Mainit Surigao del Norte, Philippines on January to April, 2021.

\section{Research design and treatment}

This experimental study was a two-factor factor experiment arranged in a Complete Randomized Design (CRD). The first factor was FCM-free and FCM supplemented while the second factor was $0 \%, 25 \%$, and $50 \%$ levels of giant swamp taro meal-based (GST) composed of 6 treatments replicated 3 times. Each replication consisted of 10 heads of 5-weeks post hatch "Bisaya" native chickens having $282.00 \pm 2.00 \mathrm{~g}$ average initial weight. The study was started at 5-weeks post hatched and terminated at 12-weeks post hatched. Treatment combinations were the following: T1 = FCM-supplemented0\% GST; T2 = FCM-supplemented-25\% GST; T3 = FCM-supplemented-50\% GST; T4 = FCM-free-0\% GST; T5 = FCM-free-25\% GST; T6 = FCM-free-50\% GST.

\section{Preparation of giant swamp taro meal}

Giant swamp taro corms were taken from Pongtud, Alegria, Surigao del Norte and adjacent barangay of Magpayang, Mainit, Surigao del Norte where SSCT-Mainit Campus experimental station was located. Preparation for Giant swamp taro corm's was in accordance by procedures of Taer and Taer (2020).

\section{Extraction of fresh coconut milk}

Mature coconuts were obtained from a farmer. Nuts were cleaned de-husked, break it open, drained the coconut water, and then mechanically grated. Every $10 \mathrm{~kg}$ of grated coconut meat was mixed with 1 liter distilled water. The mixture of coconut meat and distilled water were blended in high-speed blender for 60 seconds and poured the contents in a pan with thin muslin. The coco milk was strained, filtrate was squeezed by hand, consequently collected the fresh coconut milk in a clear bottle and store in a refrigerator until use.

\section{Experimental diet formulation and mixing of fresh coconut milk}

The experimental diets were formulated in which the chicken grower and finisher diets were calculated to contain $3000 \mathrm{ME} \mathrm{kcal} / \mathrm{kg}$ and $22 \% \mathrm{CP}$ and $2800 \mathrm{ME} \mathrm{kcal} / \mathrm{kg}$ and $20 \%$ crude protein respectively. Feed ingredients (micro and 
macro) were prepared and weighed separately according to formulation using a digital weighing scale (Table 1). Microingredients were the first to mix by hand before they were incorporated with the macro-ingredients using the mechanical mixer. The mixed feeds were partitioned into two fractions. The first fraction was allocated as GST treatment without fresh coconut milk whereas the second fraction was mixed with fresh coconut milk (FCM) at a ratio of 100ml fresh coconut milk in every kilogram of feeds. The mixing of coconut milk with the diets was done on a daily basis to avoid feed spoilage due to coconut milk addition.

\section{Data collection}

Initial weight of birds was gathered upon start of feeding trial (week - 5 post-hatch) and repeated weekly thereafter to get the weekly weight increment and weight gain. The total feed given and total feed refused were weighed and recorded daily and some birds that died during the experiment in each replicate. Feed conversion ratio (FCR) was calculated as grams of feed consumed per grams weight gain in birds in each pen. At the end of the experiment (week - 12 post-hatch), all the birds were fasted overnight, stunned electrically and slaughtered by decapitation. Slaughtered birds were scalded at $50{ }^{\circ} \mathrm{C}$ for about $1 \mathrm{~min}$, plucked manually, eviscerated and dressed. The carcass cuts (breast meat and thigh) organ (liver, gizzard, heart) were expressed as percentages $(\mathrm{g} / \mathrm{kg})$ of the live weight. On the seventh week of feeding, the daily excreta voided per cage were collected via plain G.I. sheet measuring $30 \times 60 \mathrm{~cm}$ used to catch the excreta under the cage. To avoid contamination with feeds and other contaminants, the excreta were collected every 4 hours for the period of seven days. The excreta were oven-dried at $60^{\circ} \mathrm{C}$ for 12 hours and kept frozen (-200C) until it's ready for analysis.

\section{Statistical analysis}

Data collected were subjected to ANOVA of the GLM in SPSS (SPSS for Windows, version 26.0; IBM Corp., Armonk, NY, USA), using the pen as the experimental unit for live weight, weight gain, average daily feed intake, and FCR. Slaughter weight, carcass and organ weights measured on individual birds and related to pen as the experimental unit. Treatment means were compared using the Tukey's honestly significant difference (HSD) test and differences were considered significant at $5 \%$ level of probability.

Table 1 - Composition of grower and finisher diet in the experiment (as fed-basis) Giant swamp taro root meal

\begin{tabular}{lccc|ccc}
\hline \multirow{2}{*}{ Ingredients } & \multicolumn{3}{c}{ Starter Mash } & \multicolumn{3}{c}{ Finisher Mash } \\
\cline { 2 - 7 } & Corn-based & 25\% GST & $\mathbf{5 0 \% ~ G S T ~}$ & Corn-based & 25\% GST & 50\% GST \\
\hline Yellow corn & 56.00 & 42.00 & 28.00 & 48 & 36.00 & 24.00 \\
GST & - & 14.00 & 28.00 & - & 12.00 & 24.00 \\
Rice Bran D1 & 7.00 & 7.00 & 7.00 & 15.00 & 15.00 & 15.00 \\
Soybean Meal & 16.00 & 16.00 & 16.00 & 15.00 & 15.00 & 15.00 \\
Fish meal & 14.00 & 14.00 & 14.00 & 7.00 & 7.00 & 7.00 \\
Copra meal & 4.00 & 4.00 & 4.00 & 13.00 & 13.00 & 13.00 \\
Coco oil & 1.00 & 1.00 & 1.00 & 0.50 & 0.50 & 0.50 \\
Molasses & 1.00 & 1.00 & 1.00 & 0.50 & 0.50 & 0.50 \\
Limestone & 0.25 & 0.25 & 0.25 & 0.25 & 0.25 & 0.25 \\
Salt & 0.50 & 0.50 & 0.50 & 0.50 & 0.50 & 0.50 \\
Vitamin Premix & 0.25 & 0.25 & 0.25 & 0.25 & 0.25 & 0.25 \\
Total & 100 & 100 & 100 & 100 & 100 & 100 \\
\hline
\end{tabular}

\section{RESULTS}

\section{Average daily feed intake}

Average daily feed intake (ADFI) of chickens during weeks 5-7 ranges 20.40-48.64g higher for FCM supplement, while 18.24g-47.63g lower for FCM-free ( $p<0.01$ ) chickens (Table 2). The 21.27-49.18g highly significantly ( $p<0.01$ ) different to $50 \%$ GST had $16.65-46.10 \mathrm{~g}$, however, $25 \%$ GST had $20.04-49.01 \mathrm{~g}$ did not differ to $0 \%$ GST during the same period. No ADFI differential in the FCM and GST treatments during 8-weeks grower feeding to the rest of finisher period as well no FCM*GST interactions in ADFI in the entire experiment.

\section{Live weight}

As shown in Table 3, the differences initial body weight was found to be non-significant $(p>0.05)$ whereas live weight at 5 -weeks and onwards were highly significant $(p<0.01)$. The significant to highly significant differences of live weights were constantly observed in both FCM and GST level groups. Birds with FCM supplement had higher $(p<0.01)$ body weight compared with FCM-free. Birds under 0\% GST were also higher $(p<0.01)$ in body weight from 5 weeks - 12 weeks compared to birds under $50 \%$ GST. However, the values for $25 \%$ GST birds were not significantly ( $p>0.05$ ) different to $0 \%$ GST. No significant FCM*GST interactions noted in weekly body weights of native chickens. 


\section{Weight gain}

Weekly weight gain of chickens from weeks 5-7 pot-hatch shows a highly significant $(p<0.01)$ differences between FCM supplement and FCM-free as well as in between GST levels as presented in Table 4. Increased weight gain in FCM supplement ranges $7.91-18.75 \%$ higher $(p<0.01)$ versus the FCM-free $(54.34 \mathrm{~g}$ vs. $44.15 \mathrm{~g}, 70.45 \mathrm{~g}$ vs. $59.74 \mathrm{~g}$, and $99.41 \mathrm{~g}$ vs. $92.26 \mathrm{~g}$ ), respectively. The counterpart 0\% GST was also $13.42-35.80 \%$ higher $(\mathrm{p}<0.01)$ than $50 \%$ GST within these periods. Although, the same treatment was $8.34-10.97 \%$ higher over the $25 \%$ GST but the differences were unremarkable. No remarkable weight gain differential in chickens in FCM and GST treatments during finisher phase feeding.

\section{Feed conversion ratio}

Figure 1 shows the cumulative feed conversion ratio (FCR) on native chicken fed with FCM-free and FCM supplement with levels of GST. The results showed no significant difference $(p>0.05)$ FCR values. However, an improved FCR recorded for FCM supplement (3.14) than FCM-free (3.22). The FCR for 0\% GST (3.11) was better than the FCR for 25\% GST (3.19) and $50 \%$ GST (3.26).

\section{Carcass weight, weight meat cuts and organ weight}

The summary weight of carcass component, meat cuts and weight of internal organs of native chicken are shown in Table 5. All attributes viz. dress weight, dressing percentage, breast weight, thigh weight, liver, gizzard and heart weight are not significant $(p>0.05)$ in all treatments except for abdominal fat. The FCM was 1334.27g higher than no FCM $1284.25 \mathrm{~g}$ while the $0 \%$ GST was $1352.00 \mathrm{~g}$ followed by $50 \%$ GST $1299.64 \mathrm{~g}$ then $25 \%$ GST $1276.85 \mathrm{~g}$ but their value differences were not significant.

\section{Apparent nutrient digestibility}

Apparent nutrient digestibility of crude protein, crude ash, crude fiber, and nitrogen-free extract (NFE) were tested in this study and are presented in Table 6 . The ANOVA for apparent digestibility of crude fiber showed a significant $(p<0.05)$ difference within levels of GST treatments. Apparent digestibility in crude ash revealed a significant higher digestibility in FCM treatments. The rest of the nutrients viz. apparent digestibility of crude protein and NFE showed no remarkable differences $(p>0.05)$ in all treatments.

Table 2 - Average daily feed intake of native chicken fed FCM-free and FCM supplement at different levels of GST

\begin{tabular}{|c|c|c|c|c|c|c|c|c|c|}
\hline \multirow{2}{*}{ Items } & & \multicolumn{4}{|c|}{ Grower Phase (g) } & \multicolumn{4}{|c|}{ Finisher Phase (g) } \\
\hline & & Week 5 & Week 6 & Week 7 & Week 8 & Week 9 & Week 10 & Week 11 & Week 12 \\
\hline \multirow{2}{*}{ FCM } & With FCM & $20.40^{a}$ & $32.58^{a}$ & $48.64^{a}$ & 59.52 & 70.24 & 79.26 & 89.97 & 105.92 \\
\hline & FCM-free & $18.24^{b}$ & $29.34^{b}$ & $47.63^{b}$ & 60.04 & 69.14 & 78.69 & 89.56 & 107.00 \\
\hline \multirow{3}{*}{ GST } & $0 \%$ & $21.27^{a}$ & $34.07^{a}$ & $49.28^{a}$ & 59.79 & 70.50 & 78.41 & 90.42 & 106.40 \\
\hline & $25 \%$ & $20.04^{a}$ & $32.39^{a}$ & $49.01^{a}$ & 60.21 & 69.32 & 79.93 & 89.12 & 106.90 \\
\hline & $50 \%$ & $16.65^{b}$ & $26.43^{b}$ & $46.10^{b}$ & 59.34 & 69.25 & 78.59 & 89.77 & 106.08 \\
\hline \multirow{3}{*}{$p$-Value } & FCM & 0.00777 & 0.03122 & 0.04022 & 0.43505 & 0.02468 & 0.51169 & 0.57538 & 0.29596 \\
\hline & GST & 0.00036 & 0.00024 & 0.00011 & 0.56414 & 0.06181 & 0.31701 & 0.36477 & 0.79304 \\
\hline & $\mathrm{FCM} * \mathrm{GST}$ & 0.2111 & 0.16431 & 0.13897 & 0.1408 & 0.13972 & 0.75981 & 0.28826 & 0.34422 \\
\hline
\end{tabular}

Table 3 - Weekly live weight of native chickens fed FCM-free and FCM supplement at different levels of GST

\begin{tabular}{|c|c|c|c|c|c|c|c|c|c|}
\hline \multirow{2}{*}{ Items } & & \multicolumn{4}{|c|}{ Grower Phase (g) } & \multicolumn{4}{|c|}{ Finisher Phase (g) } \\
\hline & & Week 5 & Week 6 & Week 7 & Week 8 & Week 9 & Week 10 & Week 11 & Week 12 \\
\hline \multirow{2}{*}{ FCM } & With FCM & 282.07 & $336.41^{\mathrm{a}}$ & $406.90^{a}$ & $506.33^{a}$ & $627.99^{a}$ & $777.92^{a}$ & $968.64^{a}$ & $1175.16^{a}$ \\
\hline & FCM-free & 282.15 & $326.31^{b}$ & $386.06^{b}$ & $478.33^{b}$ & $596.49^{b}$ & $739.11^{b}$ & $925.88^{b}$ & $1133.78^{b}$ \\
\hline \multirow{3}{*}{ GST } & $0 \%$ & 282.16 & $340.52^{a}$ & $415.37^{a}$ & $516.18^{a}$ & $645.48^{a}$ & $795.00^{a}$ & $985.52^{a}$ & $1196.72^{a}$ \\
\hline & $25 \%$ & 282.16 & $334.11^{a}$ & $400.91^{a}$ & $498.20^{a}$ & $616.70^{b}$ & $763.42^{a}$ & $957.23^{a}$ & $1164.92^{a}$ \\
\hline & $50 \%$ & 282.01 & $319.46^{b}$ & $373.17^{b}$ & $462.60^{b}$ & $574.54^{c}$ & $717.12^{b}$ & $899.03^{b}$ & $1101.78^{b}$ \\
\hline \multirow{3}{*}{$p$-Value } & FCM & 0.746 & 0.00181 & 0.00124 & 0.00034 & 0.00129 & 0.00435 & 0.00654 & 0.02662 \\
\hline & GST & 0.854 & 0.00006 & 0.00005 & 0.00002 & 0.00002 & 0.00034 & 0.0005 & 0.00157 \\
\hline & $\mathrm{FCM} * \mathrm{GST}$ & 0.574 & 0.64075 & 0.21454 & 0.29834 & 0.35775 & 0.30835 & 0.17798 & 0.15411 \\
\hline
\end{tabular}


Table 4 - Weight gain of native chicken fed FCM-free and FCM supplement at different levels of GST

\begin{tabular}{|c|c|c|c|c|c|c|c|c|c|}
\hline \multirow{2}{*}{ Items } & & \multicolumn{4}{|c|}{ Grower Phase (g) } & \multicolumn{4}{|c|}{ Finisher Phase (g) } \\
\hline & & Week 5 & Week 6 & Week 7 & Week 8 & Week 9 & Week 10 & Week 11 & Week 12 \\
\hline \multirow{2}{*}{$\mathrm{FCM}$} & With FCM & $54.34^{a}$ & $70.48^{a}$ & $99.41^{a}$ & 121.65 & 149.93 & 190.70 & 206.52 & 235.21 \\
\hline & FCM-free & $44.15^{b}$ & $59.74^{b}$ & $92.26^{b}$ & 118.16 & 142.61 & 186.77 & 207.90 & 233.59 \\
\hline \multirow{3}{*}{ GST } & $0 \%$ & $58.34^{a}$ & $74.84^{a}$ & $100.80^{a}$ & $129.28^{a}$ & 149.52 & 190.51 & 211.21 & 235.82 \\
\hline & $25 \%$ & $51.94 a$ & $66.79 a$ & $97.29 a$ & $118.49^{a b}$ & 146.71 & 193.81 & 207.69 & 231.18 \\
\hline & $50 \%$ & $37.45^{b}$ & $53.70^{b}$ & $89.43^{b}$ & $111.93^{b}$ & 142.59 & 181.90 & 202.74 & 236.20 \\
\hline \multirow{3}{*}{$p$-Value } & FCM & 0.00149 & 0.01634 & 0.00461 & 0.41022 & 0.18764 & 0.41319 & 0.78146 & 0.76263 \\
\hline & GST & 0.00006 & 0.00252 & 0.00218 & 0.01482 & 0.5694 & 0.13816 & 0.38607 & 0.69369 \\
\hline & $\mathrm{FCM} * \mathrm{GST}$ & 0.66868 & 0.19358 & 0.343 & 0.81042 & 0.45699 & 0.21884 & 0.16057 & 0.74115 \\
\hline
\end{tabular}

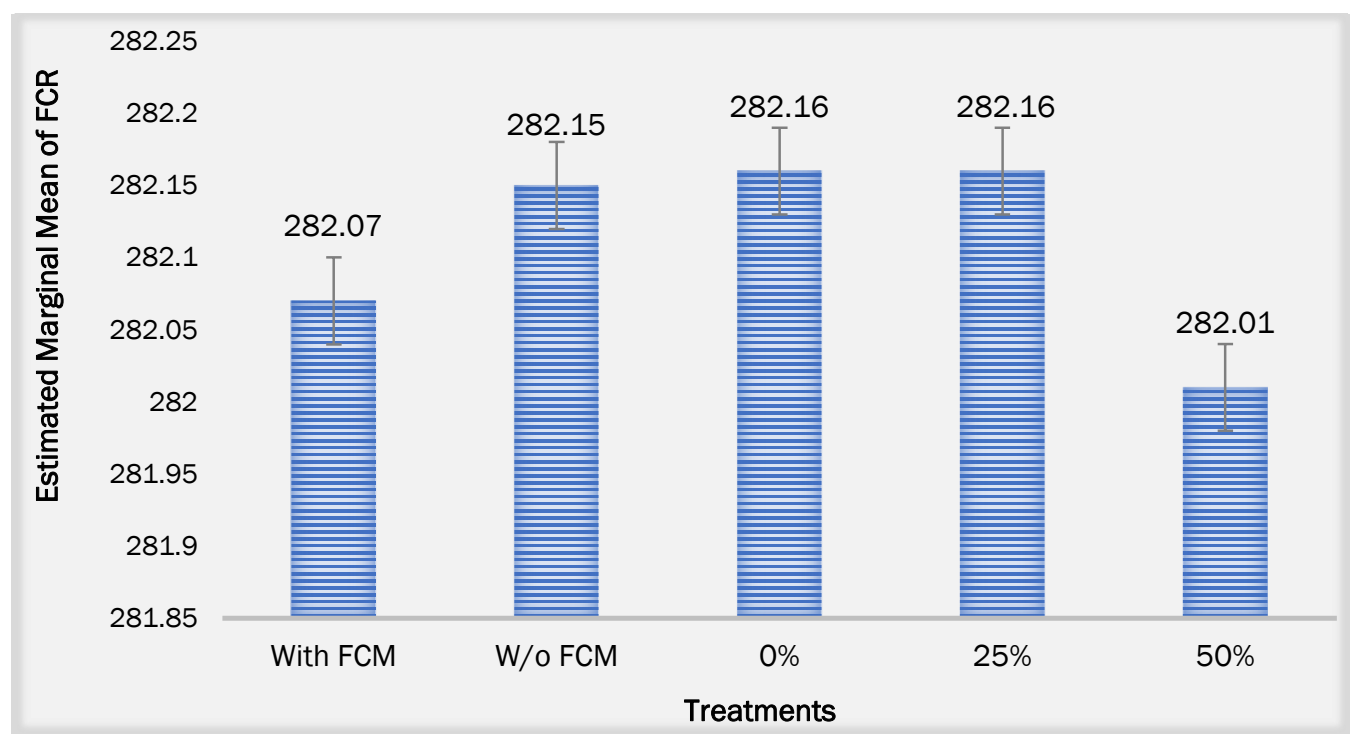

Figure 1 - Feed conversion ratio of native chicken fed FCM-free and FCM supplement at different levels of GST.

Table 5 - Carcass quality, meat cuts, and organ weights of native chicken fed FCM-free and FCM supplement at different levels of GST

\begin{tabular}{|c|c|c|c|c|c|c|c|c|c|}
\hline \multirow{2}{*}{\multicolumn{2}{|c|}{ Item }} & \multirow{2}{*}{$\begin{array}{l}\text { Slaughter } \\
\text { weight } \\
\text { (g) }\end{array}$} & \multicolumn{2}{|c|}{ Carcass Harvest } & \multicolumn{2}{|c|}{ Meat Cuts* } & \multicolumn{3}{|c|}{ Internal Organs* } \\
\hline & & & $\begin{array}{l}\text { Dress } \\
\text { weight }\end{array}$ & Dressing & Breast & Thigh & Liver & Gizzard & Heart \\
\hline \multirow{2}{*}{ FCM } & With FCM & $1334.77^{a}$ & 901.76 & 67.76 & 19.98 & 18.70 & 3.46 & 4.69 & 1.48 \\
\hline & FCM-free & $1284.25^{b}$ & 921.21 & 72.00 & 20.99 & 19.08 & 3.56 & 4.04 & 1.32 \\
\hline \multirow{3}{*}{ GST } & $0 \%$ & $1352.00^{a}$ & 911.52 & 67.57 & 20.11 & 17.10 & 3.71 & 4.60 & 1.16 \\
\hline & $25 \%$ & $1276.85^{b}$ & 924.29 & 72.58 & 22.00 & 20.13 & 2.93 & 4.04 & 1.72 \\
\hline & $50 \%$ & $1299.64^{\mathrm{ab}}$ & 898.63 & 69.49 & 19.29 & 19.53 & 3.90 & 4.46 & 1.33 \\
\hline \multirow{3}{*}{$p$ Value } & FCM & 0.01567 & 0.39346 & 0.09966 & 0.88407 & 0.73754 & 0.75311 & 0.20942 & 0.40259 \\
\hline & GST & 0.01455 & 0.6452 & 0.25994 & 0.41552 & 0.26384 & 0.05811 & 0.63211 & 0.08672 \\
\hline & $\mathrm{FCM} * \mathrm{GST}$ & 0.46286 & 0.24951 & 0.24915 & 0.89859 & 0.79448 & 0.30431 & 0.53649 & 0.32673 \\
\hline
\end{tabular}


Table 6 - Apparent digestibility of nutrient of chickens fed FCM-free and FCM supplement at different levels of GST.

\begin{tabular}{|c|c|c|c|c|c|}
\hline Item & Apparent digestibility of nutrient & Crude protein & Crude Ash & Crude fiber & NFE \\
\hline \multirow{2}{*}{ FCM } & With FCM & 54.62 & $76.16^{b}$ & 66.51 & 55.71 \\
\hline & FCM-free & 54.27 & $79.41^{a}$ & 65.91 & 55.93 \\
\hline \multirow{3}{*}{ GST } & $0 \%$ & 53.71 & 78.86 & $68.08^{a}$ & 55.24 \\
\hline & $25 \%$ & 54.85 & 76.97 & $64.91^{b}$ & 56.11 \\
\hline & $50 \%$ & 54.77 & 77.54 & $65.63^{\mathrm{ab}}$ & 56.10 \\
\hline \multirow{3}{*}{$p$ Value } & FCM & 0.52168 & 0.02667 & 0.54434 & 0.80387 \\
\hline & GST & 0.19252 & 0.49243 & 0.04514 & 0.66232 \\
\hline & $\mathrm{FCM} * \mathrm{GST}$ & 0.82205 & 0.07812 & 0.46973 & 0.16685 \\
\hline
\end{tabular}

Table 7 - Mean and standard deviations of treatment combinations on overall growth performance (body weight, weight, ADFI and FCR) of chickens fed FCM-free and FCM supplement at different levels of GST

\begin{tabular}{lcccc}
\multirow{2}{*}{ Treatment Combinations } & \multicolumn{4}{c}{ Growth Performance } \\
\cline { 2 - 5 } & Body Weight (Final) & Weight Gain (Final) & ADFI (Final) & FCR \\
\hline 0\% GST-FCM & $1435.68 \pm 51.94$ & $1153.43 \pm 11.76$ & $63.94 \pm 0.43$ & $3.11 \pm 0.12$ \\
$25 \%$ GST-FCM & $1439.94 \pm 9.98$ & $1157.74 \pm 8.19$ & $63.85 \pm 0.69$ & $3.09 \pm 0.03$ \\
$50 \%$ GST-FCM & $1355.53 \pm 46.41$ & $1073.76 \pm 4.88$ & $62.16 \pm 0.74$ & $3.25 \pm 0.10$ \\
\hline 0\% GST- FCM-free & $1429.43 \pm 15.10$ & $1147.33 \pm 12.28$ & $63.60 \pm 0.44$ & $3.10 \pm 0.53$ \\
25\% GST- FCM-free & $1352.28 \pm 51.79$ & $1070.15 \pm 17.01$ & $62.88 \pm 0.45$ & $3.29 \pm 0.14$ \\
50\% GST- FCM-free & $1320.44 \pm 41.36$ & $1038.19 \pm 8.74$ & $60.89 \pm 0.90$ & $3.29 \pm 0.08$ \\
ADFI= average daily feed intake; FCR= feed conversion ratio; GST= giant swamp taro; FCM = fresh coconut milk. & \multicolumn{4}{c}{} \\
\hline
\end{tabular}

Table 8 - Correlation analysis of live weight (final), weight gain (final), ADFI (final) and FCR of chicken

\begin{tabular}{|c|c|c|c|c|}
\hline & Live weight (Final) & Weight gain(Final) & ADFI (Final) & FCR \\
\hline Live weight (Final) & 1 & & & \\
\hline Weight gain (Final) & $1.000^{* *}$ & 1 & & \\
\hline ADFI (Final) & $0.853^{* *}$ & $0.854^{* *}$ & 1 & \\
\hline FCR & $-0.959 * *$ & $-0.958^{* *}$ & $-0.672^{*}$ & 1 \\
\hline
\end{tabular}

\section{DISCUSSION}

The aim of this study was to evaluate the effect of levels of giant swamp taro root meal as substitute to corn with and without fresh coconut milk supplementation on performance indices and differentiate its rule in feed intake and efficiency of native chicken. In this study, a decreased body weight and weight gain were consistently detected for $50 \%$ GST regardless of FCM supplementation in the entire duration of the experiment. Overall, the final body weight (Table 7) decreased in the $50 \%$ GST among levels GST treated group chickens which were inconsistent with Abdulrashid and Agwunobi (2009) using the same GST concentration or with Caicedo et al. (2018) using 40\% GST concentrations were reported no effect on productivity of broiler chickens and growing pigs, respectively. Interestingly, from week 1 - week 8 in this experiment, live weight (LW) of chickens did not differ significantly among $0 \%$ GST and $25 \%$ GST treatments. The highly significant differential in LW of $0 \%$ and $25 \%$ GST over the $50 \%$ GST indicates feed stress due to higher concentrations of anti-nutritional factors (ANF) of the diet. The higher taro inclusion, the higher concentrations of antinutritional substances in the diet. Temesgen and Retta (2015) reported that anti-nutritional elements commonly observed in all species of the Araceae family are abundant in most parts of the plant, causing throat irritation and mouth epithelium and indirectly reducing the digestibility. In FCM group, a more pronounced body weight recorded in FCM supplemented birds. The highly significant body weight of chickens under FCM treatment versus no FCM indicates 
supplementation effect of fresh coconut milk. Coconut milk consists high percentage of medium-chain fatty acid which is useful to increase weight without increasing cholesterol levels (St-Onge and Jones, 2002), rich in protein (Capulso et al., 1981) which can provide more essential amino acids for the body (Mepba and Achinewhu, 2003).

Average daily feed intake (ADFI) at weekly interval shared a similar weekly pattern with weight gain. The result indicates a positive correlation between ADFI with weight gain. Correlation analysis (Table 8) showed a highly significant positive correlation between weight gain and ADFI (0.854) whereas a perfectly positive correlation between weight gain and LW $(1.000 * *)$. This shows that increase in feed intake would lead to a higher LW and weight gain. However, correlation between weight gain, live weight (LW) and ADFI with the FCR was a very highly significant negative correlation (-0.958). Similar to BW outcome, the most improved weight gain was with $0 \%$ GST and $25 \%$ GST treated birds than did the counterpart $50 \%$ GST treatment. The result is expected as the same treatments recorded the highest average final ADFI from weeks 1-8 at 63.76g and 63.36g, respectively (Table 7) and the most efficient feed converter at 3.11 and 3.19 (Figure 1). The reduced ADFI for 50\% GST during first 3 week of experiment indicates that younger chickens do not accept the diet probably because of ANF. A major problem affecting the utilization of GST as feed ingredient has been its irritation (Pham et al., 2005), mainly due to the physical structure of oxalic acid needles that reduces palatability. The similarity in ADFI among GST treatments during 7-12 weeks in the present study suggests no palatability problem of the diets for older chickens. The improved final weight gain of chickens in FCM supplemented chickens over the no FCM can be speculated to FCM supplementation. The study of coconut milk diet supplementation to broilers exposed to environmental stress of high stocking densities found an improved immune system even when chickens were subjected to external stressors of high stocking density (Shakeri et al., 2016). In this study, feed stress to birds were apparently observed in no FCM supplementation during early weeks of feeding (5-7-weeks), whereas the higher ADFI on birds supplemented with FCM indicates no palatability problem despite ANF which probably mitigated by the FCM. However, as the birds grew older (8-12 weeks) the FCM effects were unobserved showing that older birds may have adopted the diets.

Dietary fat addition has been found to slow down digesta passage rate through the gastro-intestinal tract, allowing better nutrient digestion, absorption and utilization (Mateos et al. 1982; Latshaw, 2008), probably through increased contact with digestive enzymes. This could be a possible explanation for the improved performance of birds fed FCM despite the similarities in ADFI during last 5 weeks (8-weeks - 12-weeks) of experimentation. Dietary unsaturated fat has also been reported to increase protein accretion in broilers (Sanz et al., 2000), probably by sparing protein from being used as energy. Firman et al. (2010) observed that fat addition decreased FI and improved feed efficiency in broilers. This observation was nullified in this present study, FI was not reduced by FCM addition but rather improved the body weight, weight gain with marginal improvement in FCR. The similarities in FCR findings within FCM and GST groups was attributed to a similarly higher digestibility of crude protein as reflected in Table 6. Correlation analysis for FCR and digestibility of crude protein showed a low positive correlation of 0.216 correlation size (Figure not shown). Adequate consumption of dietary protein is critical for the maintenance of optimal health during normal growth and aging (Carbone and Pasiakos, 2019). In general, the highlight of this study was that FCM treatment performs better than no FCM supplement wherein the $25 \%$ GST plus FCM had higher final body weight and weight gain compared to the rest of treatment combinations.

All attributes, viz. dress weight, and dressing percentage, weight of meat cuts (breast and thigh) weight of internal organs (heart, gizzard, and liver) was not influenced $(P>0.05)$ by the tested diets. However, the slaughter weight of chickens in this study ranges from $1284.25-1334.77 \mathrm{~g}$ between FCM group and $1276.85-1352.00 \mathrm{~g}$ among GST group was behind the average normal slaughter weight range of 1385 - 1512g for Chee Crossbred Native Chicken raised in 12 weeks (Promket et al., 2016), 1353.13 - 1717.94g for different Aseel crosses raised for 12 weeks (Ullengala et al., 2020). The diet composition and genotype used by the works of Promket et al. (2016) and Ullengala et al. (2020) likely contributed the depressed slaughter weight observed in this present trial.

The dressing percentage was calculated as the ratio between warm carcass weight and live weight at slaughter time. The comparable dress weight and dressing percentage between GST and FCM groups for this trial aligned with dress weight of broilers fed $100 \%$ raw and boiled taro (Abdulrashid and Agwunobi, 2009) and dressing percentage of broilers fed 3-12\% sun-dried taro corm's meal (Getiso et al., 2021). The result indicates no effect of feed stress on meat harvest. However, these values were lower in dress weight and dressing percentage for Aseel crosses ranges $932.13-1194.25 \mathrm{~g}$ and $68.49-69.51 \%$, respectively (Ullengala et al., 2020).

Breast and thigh weight across different treatments were not influenced by FCM and GST addition. These results confirmed no significant changes in breast and thigh weight at $0,25,75$, and $100 \%$ raw and boiled taro inclusion reported by Abdulrashid and Agwunobi, (2009) while inconsistent with Getiso et al. (2021) who found significant breast and thigh among control and four $(3,6,9,12 \%)$ levels of sundried taro inclusion. However, the $18.92-23.24 \%$ range of breast (\%) and 17.33 - 19.98\% thigh (\%) were higher than 14.68 - 15.82\% breast (\%) for different Aseel crosses (Ullengala et al., 2020) and 12.96 - 14.10\% thigh (\%) for Chee crossbred native chicken (Promket et al., 2016). Weight of internal organs viz. liver, gizzard and heart in this study ranges $2.93-4.23,3.79-4.58$, and 1.19 - 1.66, respectively. These value ranges however, was higher over Shakeri et al. (2016) having $1.62-1.87 \%$ for liver, $3.40-3.75 \%$ for gizzard, and $0.41-0.49$ for heart. The reasons for the discrepancies on carcass harvest, weight of meat cuts and weight of organs were speculative but may be due to the different levels of added GST in the diet, age at which GST is added to diet, species, sex and native chicken genotype, chick weight at which GST was started to introduced or basal diet 
composition.

Apparent digestibility of nutrients such as crude protein, crude ash, crude fiber and nitrogen-free extract (NFE) in this study were determined. The result showed no remarkable differences in all treatments except crude fiber. The nonsignificant variations in the apparent digestible crude protein among the treatment diet may be due to high quality of the diet as apparent crude protein digestibility has been reported to depend on the source and concentration of the protein in the feed stuff (McDonald et al., 1991). This finding supports the reports of Ajetunmobi et al. (2020) on non-significant variation in the digestibility of CP, but nullifies the reports of Oso et al. (2014) and Aguihe et al. (2015) on significant variation in the digestible crude protein of broiler chickens fed cassava root meal supplemented with or without charcoal and fed cassava peel meal-based diet with enzyme Maxigrain ${ }^{\circledR}$ supplementation. The significant digestibility of crude ash in this study was higher for birds without FCM (79.41) than the FCM added diets 76.16). whereas, the non-significant results for nitrogen-free extract (NFE) nullifies the report of Ajetunmobi et al. (2020) who found a significant digestibility of NFE on birds fed varying levels of processed taro cocoyam (Colocasia esculenta) meal-based diet. Moreover, the significant findings of apparent digestibility of crude fiber among GST groups disagrees with the reports of non-significant digestibility of crude fiber for chickens fed varying levels of taro cocoyam (Ajetunmobi et al., 2020).

\section{CONCLUSION}

Supplementation of fresh coconut milk to giant swamp taro meal as replacement to maize do not reduce feed intake of chickens but rather increased body weight, weight gain with marginal improvement in FCR. The $50 \%$ giant swamp taro replacement to maize compromises overall performance of native chickens. However, supplementing fresh coconut milk to giant swamp taro meal can replace maize up to $25 \%$ that gives a better body weight, weight gain, and feed conversion ratio.

\section{DECLARATIONS}

\section{Corresponding author \\ E-mail: albinotaer74@gmail.com}

\section{Authors' contribution}

Taer A, Taer E, contribute to the research and manuscript writing. Escobal E, Alsong L, and Maglinte R. contributed the concept, diet analysis and formulation, statistical analysis and logistics.

\section{Conflict of interests}

The authors have not declared any conflict of interests.

\section{Acknowledgements}

This work was supported by the Department of Research, Development and Extension of Bachelor and Agricultural Technology (BAT) program of Surigao State College of Technology - Mainit Campus.

\section{REFERENCES}

Abdulrashid M, and Agwunobi LN (2009). Taro cocoyam (Colocasia esculenta) meal as feed ingredient in poultry. Pakistan Journal of Nutrition, 8(5): 668-673. DOI: https://dx.doi.org/10.3923/pjn.2009.668.673

Aguihe PC, Kehinde AS, Babatunde TO, and lyayi EA (2015). Effect of supplementation of cassava peel meal based diet with enzyme Maxigrain ${ }^{\circledR}$ on performance, apparent nutrient digestibility and economic indices of broiler finishers. Nigerian Journal of Animal Production, 42(1): 100-109. Link: https://njap.org.ng/index.php/njap/article/view/822/719

Ahiwe EU, Omede AA, Abdallh MB, and Iji PA (2018). Managing dietary energy intake by broiler chickens to reduce production costs and improve product quality. In B. Yücel \& T. Taşkin (Eds.), Animal Husbandry and Nutrition, pp, 115145. DOI: https://doi.org/10.5772/intechopen.76972

Ajetunmobi AW, Eguaoje SA, Adeniji CA, Omesa MT, and Iwegbu A (2020). Apparent nutrient digestibility of broiler starter fed varying levels of processed taro cocoyam (Colocasia esculenta) meal based diet. Nigerian Journal of Animal Production, 46(5). DOI: https://doi.org/10.51791/njap.v46i5.255

Anderson GH, and Moore SE (2004). Dietary proteins in the regulation of food intake and body weight in humans. The Journal of Nutrition, 134(4): 974S-979S. DOI: https://doi.org/10.1093/jn/134.4.974S

Bellisle F, Drewnowski A, Anderson GH, Westerterp-Plantenga M, and Martin CK (2012). Sweetness, satiation, and satiety. The Journal of Nutrition, 142(6): 1149S-1154S. DOI: https://doi.org/10.3945/in.111.149583

Blundell JE (1984). Serotonin and appetite. Neuropharmacology, 23(12, Part 2): 1537-1551. DOI: https://doi.org/10.1016/0028-3908(84)90098-4

Blundell JE, Burley VJ, Cotton JR, and Lawton CL (1993). Dietary fat and the control of energy intake: evaluating the effects of fat on meal size and postmeal satiety. The American Journal of Clinical Nutrition, 57(5): 772S-778S. DOI: https://doi.org/10.1093/ajcn/57.5.772S

Caicedo W, Rodríguez R, Lezcano P, Ly J, Valle S, Flores L, and Ferreira FNA (2016). Chemical composition and in vitro digestibility of silages of taro (Colocasia esculenta (L.) Schott) tubers for feeding pigs. Cuban Journal of Agricultural 
Science, 49(1): 59-64. Link: http://www.cjascience.com/index.php/CJAS/article/view/548

Capulso SA, Gonzales AL, and Celestino VG (1981). Studies on the isolation and functional characteristics of protein from coconut skim milk. Philippine Journal of Science, 110(1/2): 25-32. Link: http://scinet.dost.gov.ph/union/Downloads/24-31_67080.pdf

Carbone JW, and Pasiakos SM (2019). Dietary protein and muscle mass: Translating science to application and health benefit. Nutrients, 11(5): 1136. DOI: https://doi.org/10.3390/nu11051136

Getiso A, Asrat M, and Zeleke B (2021). Growth performance and carcass characteristics of dual-purpose "Potchefstroom Koekoek" chickens fed varying levels of raw (Sun-Dried) Boloso-1 Taro (Colocasia esculenta) corm meal. International Journal of Animal Husbandry and Veterinary Science 6(2): 14-22. Link: http://ijahvs.org/index.php/component/iresearch/?view=publication\&task=show\&id=44

Gómez F, Camps J, Simo JM, Ferré N, and Joven J (2000). Agreement study of methods based on the elimination principle for the measurement of LDL-and HDL-cholesterol compared with ultracentrifugation in patients with liver cirrhosis. Clinical Chemistry, 46(8): 1188-1191. DOI: https://doi.org/10.1093/clinchem/46.8.1188

Firman JD, Leigh H, and Kamyab A (2010). Comparison of soybean oil with an animal/vegetable blend at four levels in broiler rations from hatchto market. International Journal of Poultry Science 9(11): 1027-1030. D0I: https://doi.org/10.1155/2020/3489605

Hopkins M, Gibbons C, Caudwell P, Blundell JE, and Finlayson G (2016). Differing effects of high-fat or high-carbohydrate meals on food hedonics in overweight and obese individuals. British Journal of Nutrition, 115(10): 1875-1884. DOI: https://doi.org/10.1017/S0007114516000775

Latshaw JD (2008). Daily energy intake of broiler chickens is altered by proximate nutrient content and form of the diet. Poultry Science, 87(1): 89-95. DOI: https://doi.org/10.3382/ps.2007-00173

Mallick P, Muduli K, Biswal J N, and Pumwa J (2020). Broiler poultry feed cost optimization using linear programming technique. Journal of Operations and Strategic Planning, 3(1): 31-57. DOI: https://doi.org/10.1177/2516600X19896910

Mateos GG, Sell JL, and Eastwood JA (1982). Rate of food passage (transit time) as influenced by level of supplemental fat. Poultry Science, 61(1): 94-100. DOI: https://doi.org/10.3382/ps.0610094

McDonald P, Edward RA and Greenhalgh H (1991). Evaluation of food in: Animal nutrition (4th Edn) Longman Scientific and technical. England, Pp. 260-283.

Mepba HD, and Achinewhu SC (2003). Effects of processing on protein nutritive quality of coconut Cocos nucifera products. Plant Foods for Human Nutrition, 58(1): 15-25. DOI: https://doi.org/10.1023/A:1024006620501

Oso AO, Akapo O, Sanwo KA, and Bamgbose AM (2014). Utilization of unpeeled cassava (Manihot esculenta Crantz) root meal supplemented with or without charcoal by broiler chickens. Journal of Animal Physiology and Animal Nutrition, 98(3): 431-438. DOI: https://doi.org/10.1111/ipn.12088

Pham ST, Nguyen VL, and Dang HB (2005). Processing and use of Alocasia macrorrhiza (taro) roots for fattening pigs under mountainous village conditions. In Workshop-seminar: Making better use of local feed resources (Editors: Reg Preston and Brian Ogle) MEKARN-CTU, Cantho, pp. 23-25.

Pickering J, and Halford J (2016). Hunger. In Encyclopedia of food and health (pp. 363-368). Elsevier. DOI: https://doi.org/10.1016/B978-0-12-384947-2.00381-0

Promket D, Ruangwittayanusorn K, and Somchan T (2016). The study of carcass yields and meat quality in crossbred native chicken (Chee). Agriculture and Agricultural Science Procedia, 11: 84-89. DOI: https://doi.org/10.1016/j.aaspro.2016.12.014

Ravindran V, Tancharoenrat P, Zaefarian F, and Ravindran G (2016). Fats in poultry nutrition: Digestive physiology and factors influencing their utilisation. Animal Feed Science and Technology, 213: 1-21. D0I: https://doi.org/10.1016/i.anifeedsci.2016.01.012

Sanz M, Flores A, and Lopez-Bote CJ (2000). The metabolic use of energy from dietary fat in broilers is affected by fatty acid saturation. British Poultry Science, 41(1): 61-68. DOI: https://doi.org/10.1080/00071660086411

Samra, R. A. (2010). Fats and satiety. In J.-P. Montmayeur \& J. le Coutre (Eds.), Fat detection: Taste, texture, and post ingestive effects. CRC Press/Taylor and Francis. Link: https://pubmed.ncbi.nlm.nih.gov/21452477/

Shakeri M, Oskoueian E, and Najafi P (2016). Impact of diet supplemented by coconut milk on corticosterone and acute phase protein level under high stocking density. İstanbul Üniversitesi Veteriner Fakültesi Dergisi, 42(1): 26-30. DOI: https://doi.org/10.16988/iuvfd.2016.80560

Skinner JT, Waldroup AL, and Waldroup PW (1992). Effects of dietary nutrient density on performance and carcass quality of broilers 42 to 49 days of age. Journal of Applied Poultry Research, 1(4): 367-372. DOI: https://doi.org/10.1093/japr/1.4.367

St-Onge MP, and Jones PJH (2002). Physiological effects of medium-chain triglycerides: Potential agents in the prevention of obesity. The Journal of Nutrition, 132(3): 329-332. DOI: https://doi.org/10.1093/jn/132.3.329

Taer AN, and Taer EC (2020). Proximate analysis and mineral composition of selected root crops as a source of energy in poultry diets. Journal of Environmental Science, Computer Science and Engineering \& Technology. 9(2), 308-314. DOI: https://doi.org/10.24214/jecet.A.9.2.30814

Temesgen M, and Retta N (2015). Nutritional potential, health and food security benefits of taro Colocasia esculenta (L.): A review. Food Science and Quality Management, 36: 23-30. Link: https://www.iiste.org/Journals/index.php/FSQM/article/download/19775/20137

Temesgen M, Retta N, and Tesfaye E (2017). Nutrient composition and digestibility of taro leaf in the diets of chicken and effects on the meat quality. Journal of Nutritional Health \& Food Engineering, 7(3): $00238 . \quad$ Link: 
https://medcraveonline.com/JNHFE/nutrient-composition-and-digestibility-of-taro-leaf-in-the-diets-of-chicken-andeffects-on-the-meat-quality.html

Ullengala R, Paswan C, Prince LLL, Muthukumar M, Haunshi S, Reddy BL, and Chatterjee R (2020). Studies on growth, carcass and meat quality traits in Aseel crosses suitable for small scale intensive broiler farming. Journal of Applied Animal Research, 48(1): 507-514. DOI: https://doi.org/10.1080/09712119.2020.1837137

Van Citters GW, and Lin HC (1999). The ileal brake: A fifteen-year progress report. Current Gastroenterology Reports, 1(5), 404-409. DOI: https://doi.org/10.1007/s11894-999-0022-6

Van Der Klis JD (2010). Energy in Poultry Diets: Adjusted AME or Net Energy J D. Van Der Klis, C. Kwakernaak, A. Jansman 2 and M. Blok 3. In 21st Annual Australian Poultry Science Symposium, p. $44 . \quad$ Link: https://researchoutput.csu.edu.au/ws/portalfiles/portal/9683185/12637_Chousalkar_APSS\%26\%2320\%3Bproceed ings.pdf

Van Wymelbeke V, Himaya A, Louis-Sylvestre J, and Fantino M (1998). Influence of medium-chain and long-chain triacylglycerols on the control of food intake in men. The American Journal of Clinical Nutrition, 68(2): 226-234. DOI: https://doi.org/10.1093/ajcn/68.2.226

Wallace TC (2019). Health effects of coconut oil-A narrative review of current evidence. Journal of the American College of Nutrition, 38(2): 97-107.Doi: https://doi.org/10.1080/07315724.2018.1497562 